TITLE:

History versus Expectations in Economic Geography Reconsidered(Mathematical Economics)

\author{
$\operatorname{AUTHOR}(S)$ :
}

OYAMA, DAISUKE

CITATION:

OYAMA, DAISUKE. History versus Expectations in Economic Geography

Reconsidered(Mathematical Economics). 数理解析研究所講究録 2007, 1557: 58-58

ISSUE DATE:

2007-05

URL:

http://hdl.handle.net/2433/81026

RIGHT: 


\title{
History versus Expectations in Economic Geography Reconsidered
}

\author{
DAISUKE OYAMA \\ Graduate School of Economics, Hitotsubashi University \\ oyama@econ.hit-u.ac.jp
}

\begin{abstract}
This paper considers a class of adjustment dynamics with forward-looking migrants in a new economic geography model à la Krugman (1991a). Specifically, we employ the equilibrium dynamics due to Krugman (1991b) and Fukao and Benabou (1993), where migration incurs moving costs which depend on the size of the current migration flow, so that migrants care about the future migration behavior of the economy. Our main goal is to identify a state that is absorbing (i.e., if the initial state is in a neighborhood of this state, then any equilibrium path converges to it) and globally accessible (i.e., for any initial state, there exists an equilibrium path that converges to this state) when the degree of friction is small (i.e., the migration cost and/or the rate of time preference is small). We show that such a state generically exists (which is unique by definition) and is characterized as a unique maximizer of a potential function of the static model.

The proof strategy for our result follows that of Hofbauer and Sorger (1999), who study stability under a different class of perfect foresight dynamics, due to Matsui and Matsuyama (1995), in potential games. We first show that equilibrium paths in our dynamics are solutions to a certain optimal control problem with state variable inequality constraints (see, e.g., Hartl et al. (1995)). Global accessibility is then shown by a turnpike theorem for the optimal control problem, while absorption follows from the observation that the maximized Hamiltonian of the optimal control problem serves as a Lyapunov function for bounded trajectories.
\end{abstract}

THE PAPER IS AVAILABLE AT:

http://www.econ.hit-u.ac.jp/ oyama/papers/hist-vs-exp.html

\section{References}

FuKaO, K. AND R. Benabou (1993). "History versus Expectations: A Comment," Quarterly Journal of Economics 108, 535-42.

HARTL, R. F., S. P. SETHI, AND R. G. ViCKSON (1995). "A Survey of the Maximum Principles for Optimal Control Problems with State Constraints," SIAM Review 37, 181-218.

Hofbauer, J. AND G. Sorger (1999). "Perfect Foresight and Equilibrium Selection in Symmetric Potential Games," Journal of Economic Theory 85, 1-23.

Krugman, P. (1991a). "Increasing Returns and Economic Geography," Journal of Political Economy 99, 483-499.

KRUgman, P. (1991b). "History versus Expectations," Quarterly Journal of Economics 106, 651-67.

Matsui, A. AND K. MatsuYama (1995). "An Approach to Equilibrium Selection," Journal of Economic Theory 65, 415-434. 